\title{
SINTESIS SURFAKTAN ALKIL POLIGLIKOSIDA (APG) BERBASIS DODEKANOL DAN HEKSADEKANOL DENGAN REAKTAN GLUKOSA CAIR 75\%
}

\section{SYNTHESIS OF ALKYL POLIGLYCOSIDES SURFACTANT BASED ON DODECANOL AND HEXADECANOL WITH LIQUID GLUCOSE 75\% AS REACTANT}

\author{
Fina Uzwatania ${ }^{1}{ }^{*}$, Erliza Hambali ${ }^{1,2)}$, dan Ani Suryani ${ }^{1,2)}$ \\ ${ }^{1)}$ Program Studi Teknologi Industri Pertanian, Sekolah Pascasarjana, Institut Pertanian Bogor \\ J1. Raya Darmaga, Kampus IPB Darmaga, Bogor 16680, Indonesia \\ ${ }^{2)}$ Pusat Penelitian Surfaktan dan Bioenergi, LPPM IPB \\ Jl.Raya Pajajaran, Kampus IPB Baranangsiang, Bogor 16153, Indonesia \\ Email: erliza.h@gmail.com
}

Makalah: Diterima 21 Juni 2015; Diperbaiki 3 Juni 2016; Disetujui 6 Maret 2017

\begin{abstract}
Alkyl poliglucosides (APG) is nonionic surfactant prepared from renewable raw materials based on carbohydrate and vegetable oils namely glucose and fatty alcohol. Glucose is the main raw material which is supplied the hydrophilic group, and fatty alcohol as hydrophobic group. APG was prepared using fatty alcohol varying in chain lengthsof $C_{12}$ and $C_{16}$ by two step methods (butanolysis and transasetalisation process). The catalyst of methyl ester sulfonic acid (MESA) was added. The effect of catalyst concentrations (1.5, 2, and 2.5\%) was investigated. The product evaluated for surface active properties. The chemical structures of the products were confirmed using fourier transform infrared spectroscopy (FTIR).The effects of fatty alcohol and concentration of catalyst were not significantly different to the $\mathrm{pH}$ and density. The result showed that reduction surface tension, reduction interfacial tension, and emulsion stability increased with increasing alkyl chain length and foam height decreases as the alkyl chain length increases. The best APG was obtained from $C_{16}$ fatty alcohol (hexadecanol) and $2.5 \%$ of MESA catalyst, with the ability to reduce surface tensions at $1 \%$ concentration were $68.12 \%$; the ability to reduce interfacial tensions of $98.14 \%$, stability of emulsion of $64 \%$, foam height of $7.12 \%$ and $\mathrm{pH}$ of 7.69 .
\end{abstract}

Keywords: alkylpoliglycoside, fatty alcohol, glucose, surfactant

\section{ABSTRAK}

Alkil poliglikosida (APG) merupakan surfaktan non ionik yang dihasilkan dari bahan baku yang dapat diperbaharui berbasis karbohidrat dan minyak nabati yaitu glukosa dan alkohol lemak. Glukosa merupakan bahan baku utama yang membentuk gugus hidrofilik dan alkohol lemak membentuk gugus hidrofobik. Surfaktan APG disintesis dengan menggunakan alkohol lemak dengan panjang rantai $\mathrm{C}_{12}$ dan $\mathrm{C}_{16}$ melalui proses dua tahap (butanolisis dan transasetalisasi) yang dikatalisis oleh methyl ester sulfonic acid (MESA). Pengamatan dilakukan terhadap sifat fisiko kimia dan aktivitas permukaan dari APG yang dihasilkan sebagai fungsi konsentrasi MESA (1,5; 2 dan 2,5\%). Struktur kimia dari produk APG dianalisis menggunakan FTIR. Jenis alkohol lemak dan konsentrasi katalis tidak berpengaruh nyata terhadap $\mathrm{pH}$ dan densitas. Hasil analisis terhadap surfaktan APG menunjukkan bahwa kemampuan menurunkan tegangan permukaan dan tegangan antarmuka serta stabilitas emulsi meningkat dengan semakin panjang rantai alkil dan tinggi busa menurun dengan semakin panjang rantai alkil. Surfaktan APG kombinasi perlakuan jenis alkohol lemak $\mathrm{C}_{16}$ dengan konsentrasi katalis MESA 2,5\% memiliki karakteristik nilai rata-rata kemampuan menurunkan tegangan permukaan pada konsentrasi $1 \%$ sebesar $68,12 \%$, kemampuan menurunkan tegangan antarmuka 98,14\%, stabilitas emulsi $64 \%$, pH 7,69 dan pembusaan $7,12 \%$.

Kata kunci : alkil poliglikosida, alkohol lemak, glukosa, surfaktan

\section{PENDAHULUAN}

Alkil poliglikosida (APG) merupakan surfaktan yang terbuat dari bahan-bahan alami terbarukan, yaitu dari karbohidrat dan alkohol lemak. APG dapat digunakan sebagai aditif pada formulasi beberapa produk seperti herbisida, produkproduk perawatan diri (personal care products), kosmetik maupun untuk pemucatan kain/tekstil. Alkil poliglikosida merupakan surfaktan yang bersifat nonionik karena pada gugus polar (hidrofilik) dan non polar (hidrofobik) tidak bermuatan. Sifat hidrofobiknya terdapat pada gugus alkil alkohol lemak dan sifat hidrofiliknya terdapat pada molekul glukosa. Surfaktan APG ini tidak berbahaya untuk mata, kulit dan membran, mengurangi efek iritan serta dapat terurai dengan baik secara aerob dan anaerob (Mehling et al., 2007).

Indonesia merupakan negara penghasil kelapa sawit. Data Badan Pusat Statistik (2015) menyatakan pada tahun 2013 produksi minyak 
kelapa sawit (Crude Palm Oil/CPO) sebesar 26.895.500 ton dan produksi minyak inti sawit (Palm Kernel Oil/PKO) sebesar 5.549.200 ton. Minyak sawit dan minyak inti sawit merupakan bahan baku untuk menghasilkan alkohol lemak (fatty alcohol). Selain itu Indonesia merupakan salah satu negara penghasil ubi kayu, dimana jumlah produksi ubi kayu pada tahun 2014 sebesar 23.458.128 ton dengan luas area 1.003.293 ha. Tingginya produksi minyak kelapa sawit, minyak inti sawit dan ubi kayu membuat Indonesia sangat berpeluang untuk memproduksi APG.

Surfaktan APG dapat diproduksi dengan metode Fischer secara langsung (asetalisasi) dan secara tidak langsung melalui dua tahap yaitu butanolisis dan transasetalisasi dan selanjutnya melalui tahapan netralisasi dan distilasi. Sintesis APG melalui proses dua tahap menggunakan glukosa dan alkohol lemak dengan panjang rantai yang berbeda telah dilakukan oleh Ware et al. (2007) dengan 5 rantai karbon yang berbeda yaitu oktanol $\left(\mathrm{C}_{8}\right)$, dekanol $\left(\mathrm{C}_{10}\right)$, dodekanol $\left(\mathrm{C}_{12}\right)$, heksadekanol $\left(\mathrm{C}_{16}\right)$, dan oktadekanol $\left(\mathrm{C}_{18}\right)$ serta El-Sukkary et al. (2008) dengan panjang rantai alkil berbeda, yaitu oktanol $\left(\mathrm{C}_{8}\right)$, nonanol $\left(\mathrm{C}_{9}\right)$, dekanol $\left(\mathrm{C}_{10}\right)$, dodekanol $\left(\mathrm{C}_{12}\right)$ dan tetradekanol $\left(\mathrm{C}_{14}\right)$. Proses sintesis APG disajikan pada Gambar 1.

Umumnya katalis yang digunakan adalah $p$ toluene-sulfonic acid (PTSA) (Ware et al., 2007; ElSukkary et al., 2008). Pada penelitian ini dilakukan percobaan dengan menggunakan katalis MESA sebagai alternatif katalis yang lebih ramah lingkungan dan terbarukan dari minyak sawit.

Sakarida yang dapat digunakan untuk memproduksi APG diantaranya glukosa, fruktosa, manosa, galaktosa, xilosa, pati, sukrosa, laktosa dan lain sebagainya baik dalam bentuk cairan maupun padatan. Penggunaan glukosa dan pati lebih banyak digunakan dengan alasan ketersediaan dan biaya yang murah (O'Lenick, 2007). Proses pembuatan APG masih didominasi oleh penggunaan pati kentang dan jagung sebagai gugus hidrofilik dan alkohol lemak $\mathrm{C}_{14}-\mathrm{C}_{18}$ sebagai sumber gugus hidrofobik (Hill, 2009). Penelitian dengan menggunakan pati sagu telah dilakukan oleh Suryani et al. (2008) dan tapioka oleh Bastian et al. (2012). Pada penelitian ini digunakan glukosa cair $75 \%$ berbasis ubi kayu. Tujuan dari penelitian ini adalah mengetahui pengaruh jenis alkohol lemak (fatty alcohol) $\mathrm{C}_{12}$ dan $\mathrm{C}_{16}$ serta pengaruh konsentrasi katalis MESA terhadap karakteristik Alkil Poliglikosida (APG) yang dihasilkan.

\section{BAHAN DAN METODE}

\section{Bahan dan Alat}

Bahan-bahan yang digunakan untuk sintesis alkil poliglikosida adalah alkohol lemak $\mathrm{C}_{12}$ (dodekanol) dan $\mathrm{C}_{16}$ (heksadekanol) yang diperoleh dari PT. Ecogreen Oleokimia, glukosa cair $75 \%$ yang diperoleh dari PT. Raya Sugarindo Inti, butanol, aquades, katalis MESA (methyl ester sulfonic acid), dan $\mathrm{NaOH} 50 \%$.

Peralatan yang digunakan untuk sintesis dan analisa surfaktan alkil poliglikosida (APG) adalah reaktor berpengaduk, hot plate magnetic stirrer, timbangan, gelas ukur, gelas piala, $\mathrm{pH}$ meter, erlenmeyer, pipet dan termometer.

\section{Sintesis APG}

Sintesis APG dilakukan dengan dua tahap yaitu butanolisis dan transasetalisasi. Proses butanolisis dilakukan pada reaktor dengan mencampurkan glukosa cair $75 \%$ dengan butanol dengan rasio mol 1 : 5,9 dan katalis methyl ester sulfonic acid (MESA) dengan konsentrasi 1,5; 2 dan $2,5 \%$ dari berat glukosa. Kondisi proses pada suhu $130^{\circ} \mathrm{C}-150^{\circ} \mathrm{C}$ dengan tekanan 3-5 bar selama 30 menit. Setelah proses butanolisis dilanjutkan dengan proses transasetalisasi dengan mencampurkan hasil proses butanolisis dengan alkohol lemak (fatty alcohol) dan katalis methyl ester sulfonic acid (MESA) sebanyak 50\% dari jumlah katalis pada proses butanolisis.

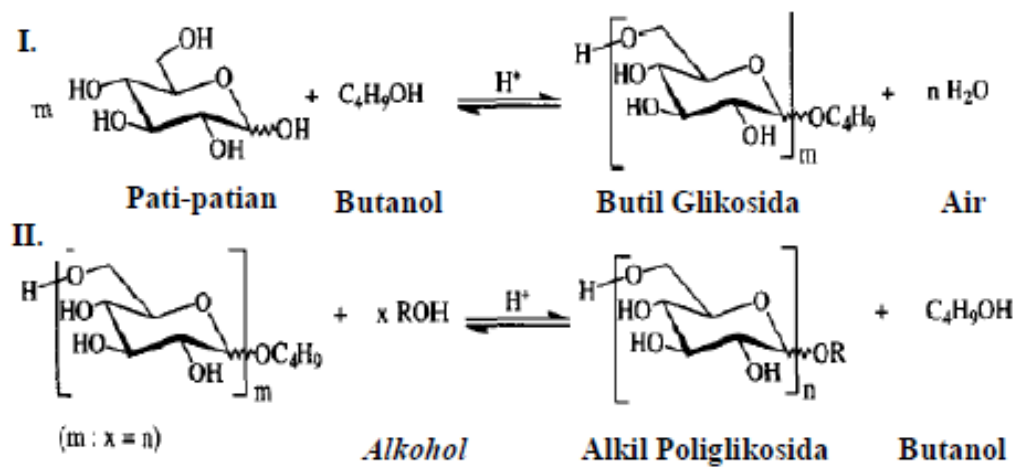

Gambar 1. Proses sintesis APG dua tahap (Hill, 2000) : (I) Reaksi butanolisis (II) Reaksi transasetalisasi 
Rasio mol glukosa dan alkohol lemak adalah $1: 3$. Proses transasetalisasi pada suhu 120$130^{\circ} \mathrm{C}$ dengan kondisi vakum $15-25 \mathrm{mmHg}$ selama 2 jam. Campuran bahan hasil transasetalisasi didinginkan hingga mencapai suhu $80-90^{\circ} \mathrm{C}$ yang kemudian dilakukan netralisasi sampai $\mathrm{pH}$ 8-10 dengan menggunakan $\mathrm{NaOH} 50 \%$. Selanjutnya proses distilasi yang bertujuan untuk mengeluarkan alkohol lemak yang tidak bereaksi pada suhu 160 $180^{\circ} \mathrm{C}$ dan tekanan vakum $15 \mathrm{mmHg}$ selama 2 jam.

\section{Sifat Fisiko Kimia dan Kinerja Surfaktan APG}

Pengamatan pengaruh perlakuan terhadap APG yang dihasilkan yaitu analisis sifat fisiko kimia meliputi pH, densitas dan FTIR (Fourier Transform Infra Red Spectroscopy) serta uji kinerja meliputi tegangan permukaan, tegangan antarmuka, stabilitas emulsi dan pembusaan.

Analisa uji $\mathrm{pH}$ dengan menggunakan $\mathrm{pH}$ meter Schott, pengukuran densitas atau bobot jenis dilakukan dengan density meter Anton Paar DMA $4500 m$ dan analisa gugus fungsi FTIR menggunakan Bruker Tensor 37. Analisa tegangan permukaan dan tegangan antarmuka dilakukan dengan menggunakan Spinning Drop Tensiometer merek TV 500c.

\section{Rancangan Percobaan}

Rancangan percobaan yang digunakan adalah Rancangan Acak Lengkap (RAL) faktorial dengan dua faktor dan dua kali ulangan. Faktor yang digunakan adalah jenis alkohol lemak yang digunakan (A) dengan 2 taraf $\left(\mathrm{C}_{12}\right.$ dan $\left.\mathrm{C}_{16}\right)$ dan konsentrasi katalis MESA pada proses butanolisis (B) dengan 3 taraf $(1,5 \%, 2 \%, 2,5 \%$ dari berat glukosa). Model yang digunakan :

$$
Y_{i j k}=\mu+A_{i}+B_{j}+(A B)_{i j}+\varepsilon_{i j k}
$$

Keterangan:

$$
\begin{aligned}
& \mathrm{Y}_{\mathrm{ijk}}=\text { Nilai pengamatan akibat pengaruh } \\
& \mu \quad=\quad \text { Rataan umum } \\
& \mathrm{A}_{\mathrm{i}} \quad=\text { Pengaruh faktor } \mathrm{A} \text { (jenis alkohol }
\end{aligned}
$$

\section{HASIL DAN PEMBAHASAN}

\section{Sintesis Surfaktan APG}

Sintesis surfaktan APG dilakukan melalui proses butanolisis, transasetalisasi, netralisasi dan diakhiri dengan proses distilasi menggunakan reaktor berpengaduk dengan kapasitas $2 \mathrm{~L}$ terbuat dari stainless steel yang dilengkapi dengan thermoset digital untuk mengatur suhu dengan memanaskan silicon oil sebagai media pemanas, thermocoupel untuk mengetahui suhu di dalam reaktor serta indikator tekanan. Pengaduk dalam reaktor menggunakan pengaduk jenis propeller (baling-baling) dan pada bagian dinding dalam reaktor dilengkapi dengan baffle.

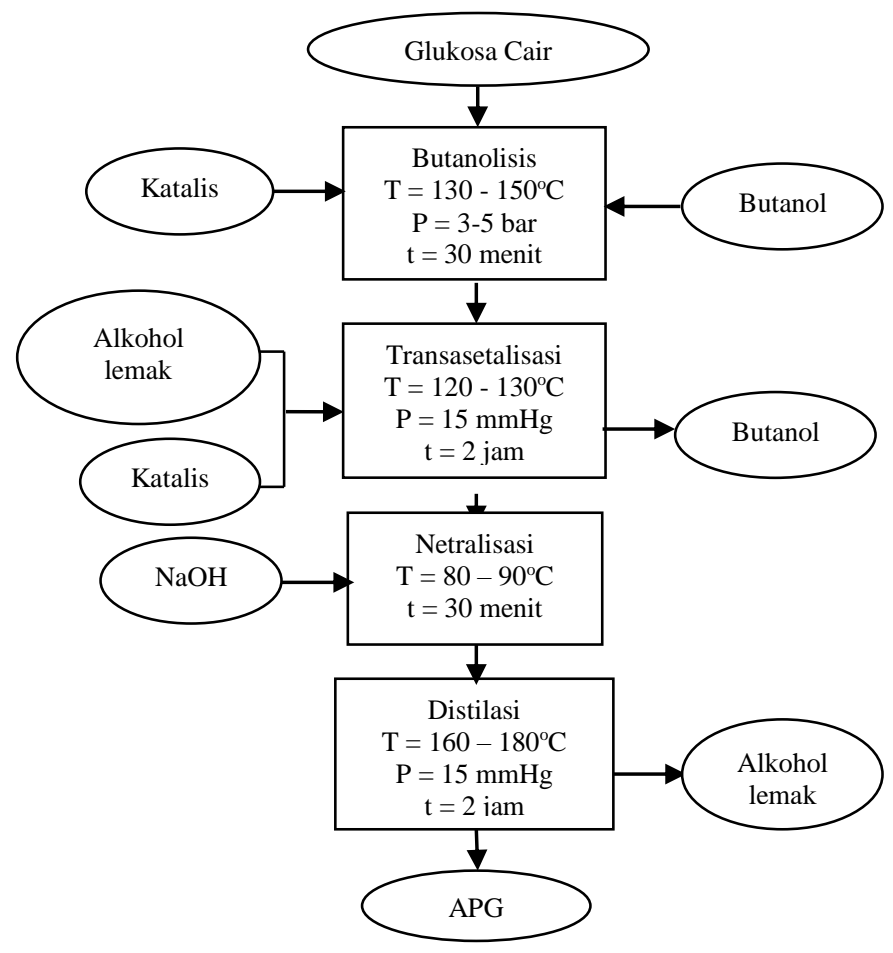

Gambar 2. Diagram alir sintesis APG 
Tutup reaktor dilengkapi dengan kran yang dihubungkan dengan barometer tekanan tinggi dan barometer vakum dan pendingin. Seal antara penutup reaktor dengan reaktor menggunakan seal silicon yang tahan sampai suhu $200^{\circ} \mathrm{C}$. Proses sintesis APG dua tahap diawali oleh proses butanolisis. Penggunaan bahan baku sakarida yang memiliki dextrose equivalent (DE) yang rendah seperti glukosa cair melalui proses butanolisis terlebih dahulu (Eskuchen dan Michael, 1997). Dengan proses penambahan berbagai konsentrasi katalis diharapkan butil glikosida yang terbentuk akan menjadi maksimal.

Tahap butanolisis menghasilkan larutan yang berwarna coklat muda terdiri dari butil glikosida, kelebihan butanol dan residu. Menurut Luders (2000), penggunaan suhu tinggi pada proses sintesis maka reaksi akan berjalan lebih cepat, namun proses harus dijaga untuk meminimalkan pembentukan by-product yang tidak diinginkan. Penambahan katalis yang semakin tinggi memungkinkan terjadinya kondisi keasaman yang semakin tinggi selama proses butanolisis. Dengan suasana asam memungkinkan ion $\mathrm{H}^{+}$yang diperoleh dari katalis membantu terjadinya ikatan antara gula dan butanol.

Setelah proses transasetalisasi didapatkan hasil berupa cairan berwarna coklat muda. Derajat keasaman larutan yang dihasilkan yaitu $\mathrm{pH} 4$ - 5 . McCurry (1994), menyatakan bahwa larutan hasil proses transasetalisasi terdiri dari dodecil poliglikosida, alkohol lemak berlebih, polidekstrosa dan sebagian kecil gula yang tidak ikut bereaksi dengan alkohol lemak. Proses netralisasi dilakukan untuk menghentikan proses transasetalisasi. Jika tidak dilakukan netralisasi maka APG yang telah terbentuk dalam larutan hasil transasetalisasi akan mengalami kerusakan pada proses destilasi. Hal ini disebabkan karena larutan masih bersifat asam dan suhu yang digunakan $>140^{\circ} \mathrm{C}$ yang dapat merusak APG yang telah terbentuk. Pada proses netralisasi, konsentrasi katalis MESA yang digunakan akan berpengaruh pada jumlah basa yang digunakan.

Hasil akhir proses destilasi akan diperoleh APG kasar berbentuk pasta yang berwarna coklat kehitaman yang akan segera mengeras pada suhu ruang. APG hasil sintesis berbentuk padatan sedangkan APG komersial bersifat cairan kental berwarna keruh transparan. Hal ini disebabkan karena APG komersial mengkombinasikan alkohol lemak $\mathrm{C}_{8}, \mathrm{C}_{10}, \mathrm{C}_{12}$ dan $\mathrm{C}_{14}$. Menurut Ware et al. (2007) sintesis APG menggunakan alkohol lemak $\mathrm{C}_{8}$ dan $\mathrm{C}_{10}$ akan menghasilkan APG yang bersifat cairan kental, sedangkan menggunakan alkohol lemak dengan jumlah C yang lebih tinggi, APG yang dihasilkan akan berbentuk padat pada suhu kamar.

\section{Sifat Fisiko Kimia Surfaktan APG Densitas}

Analisis densitas larutan surfaktan diukur dengan menggunakan density meter. Larutan surfaktan APG dilarutkan dalam air dengan konsentrasi 0,$5 ; 1 ; 1,5 ; 2$ dan 2,5\%. Densitas larutan surfaktan diperlukan untuk mengetahui besarnya kemampuan surfaktan dalam menurunkan tegangan permukaan dan tegangan antarmuka. Rata-rata densitas surfaktan APG hasil sintesis disajikan pada Tabel 1.

Hasil menunjukkan densitas berbagai konsentrasi larutan surfaktan APG yang diamati berkisar antara $0,9966-1,001 \mathrm{~kg} / \mathrm{m}^{3}$. Berdasarkan hasil analisis ragam $(\alpha=0,05)$ jenis alkohol lemak, konsentrasi katalis dan interaksi antara kedua faktor tidak berpengaruh nyata terhadap nilai densitas surfaktan APG. Hal ini dapat disebabkan pada setiap sampel hasil sintesis, terkandung komponen utama yang sama. Dengan demikian, nilai densitas masingmasing sampel tidak terlalu berbeda jauh satu sama lain.

pH

Uji $\mathrm{pH}$ dilakukan untuk mengetahui tingkat keasaman surfaktan APG yang dihasilkan. Pengukuran $\mathrm{pH}$ menggunakan alat $\mathrm{pH}$ meter. Pengujian dilakukan dengan melarutkan APG yang berupa padatan dalam air dengan konsentrasi $1 \%$ (b/v). Hasil pengamatan menunjukkan APG yang dihasilkan memiliki pH pada kisaran 7 - 8. Kondisi basa pada APG diperoleh pada proses netralisasi dengan penambahan $\mathrm{NaOH} 50 \%$. APG merupakan suatu asetal, dimana asetal akan lebih stabil pada kondisi netral dan lebih baik lagi dalam kondisi basa.

Tabel 1. Rata-rata densitas surfaktan APG hasil sintesis

\begin{tabular}{cccccc}
\hline \multirow{2}{*}{$\begin{array}{c}\text { Kombinasi } \\
\text { Perlakuan }\end{array}$} & $\mathbf{0 , 5 \%}$ & $\mathbf{1 \%}$ & $\mathbf{1 , 5 \%}$ & $\mathbf{2 \%}$ & $\mathbf{2 , 5 \%}$ \\
\cline { 2 - 6 } & $0,9966 \pm 0,0000$ & $0,9972 \pm 0,0001$ & $0,9981 \pm 0,0004$ & $0,9987 \pm 0,0009$ & $1,0004 \pm 0,0002$ \\
A1B1 & $0,9967 \pm 0,0001$ & $0,9976 \pm 0,0000$ & $0,9985 \pm 0,0002$ & $0,9992 \pm 0,0001$ & $1,0001 \pm 0,0004$ \\
A1B2 & $0,9969 \pm 0,0001$ & $0,9977 \pm 0,0000$ & $0,9985 \pm 0,0001$ & $0,9993 \pm 0,0004$ & $1,0002 \pm 0,0000$ \\
A1B3 & $0,9965 \pm 0,0000$ & $0,9972 \pm 0,0003$ & $0,9980 \pm 0,0004$ & $0,9989 \pm 0,0005$ & $0,9996 \pm 0,0011$ \\
A2B1 & $0,9965 \pm 0,0002$ & $0,9973 \pm 0,0005$ & $0,9982 \pm 0,0007$ & $0,9989 \pm 0,0010$ & $0,9996 \pm 0,0012$ \\
A2B2 & $0,9965 \pm 0,0003$ & $0,9973 \pm 0,0004$ & $0,9981 \pm 0,0006$ & $0,9991 \pm 0,0004$ & $0,9995 \pm 0,0011$ \\
A2B3 & & & & & \\
\hline
\end{tabular}


Tabel 2. Rata-rata pH surfaktan APG hasil sintesis

\begin{tabular}{cc}
\hline Kombinasi Perlakuan & $\mathbf{p H}$ \\
\hline A1B1 & $7,57 \pm 0,07$ \\
A1B2 & $7,52 \pm 0,14$ \\
A1B3 & $7,66 \pm 0,26$ \\
A2B1 & $7,72 \pm 0,29$ \\
A2B2 & $7,73 \pm 0,13$ \\
A2B3 & $7,69 \pm 0,17$ \\
\hline
\end{tabular}

\section{FTIR}

Spektrofotometer infra merah transformasi fourier (FTIR) merupakan alat untuk mendeteksi gugus fungsi suatu senyawa dengan spektrum infra merah dari senyawa organik yang memiliki sifat fisik yang khas. Hasil analisa FTIR menunjukkan pola serapan yang hampir sama antara $A P G C_{16}$ dan APG $\mathrm{C}_{12}$. Gugus eter $(\mathrm{C}-\mathrm{O}-\mathrm{C})$ pada APG $\mathrm{C}_{12}$ terdapat dari serapan bilangan gelombang 1.152,26 $\mathrm{cm}^{-1}$ sedangkan APG $\mathrm{C}_{16}$ terdapat pada serapan bilangan gelombang $1.152,60 \mathrm{~cm}^{-1}$. Gugus $\mathrm{OH}$ pada APG $\mathrm{C}_{12}$ terdapat pada serapan bilangan gelombang $3.369,29 \mathrm{~cm}^{-1}$ sedangkan APG $\mathrm{C}_{16}$ terdapat pada serapan bilangan gelombang $3397,29 \mathrm{~cm}^{-1}$.

Hal ini sesuai pendapat Sukkary et al. (2007), bahwa gugus eter (C-O-C) sebagai komponen gugus utama pada APG terdapat pada serapan bilangan gelombang 1.120-1.170 $\mathrm{cm}^{-1}$, sedangkan gugus $\mathrm{OH}$ terbentuk pada serapan bilangan gelombang $3.200-3400 \mathrm{~cm}^{-1}$. Hasil spektra gugus fungsi FTIR surfaktan APG dapat dilihat pada Gambar 4 dan 5. Terbentuknya gugus eter (C-O-C) menandakan bahwa sintesis antara gugus hidroksil dari pati dengan alkohol lemak telah terbentuk, yang berarti struktur gugus hidrofobik dari surfaktan APG juga telah terbentuk. Gugus $\mathrm{OH}$ menandakan gugus hidrofilik dari surfaktan APG telah terbentuk.

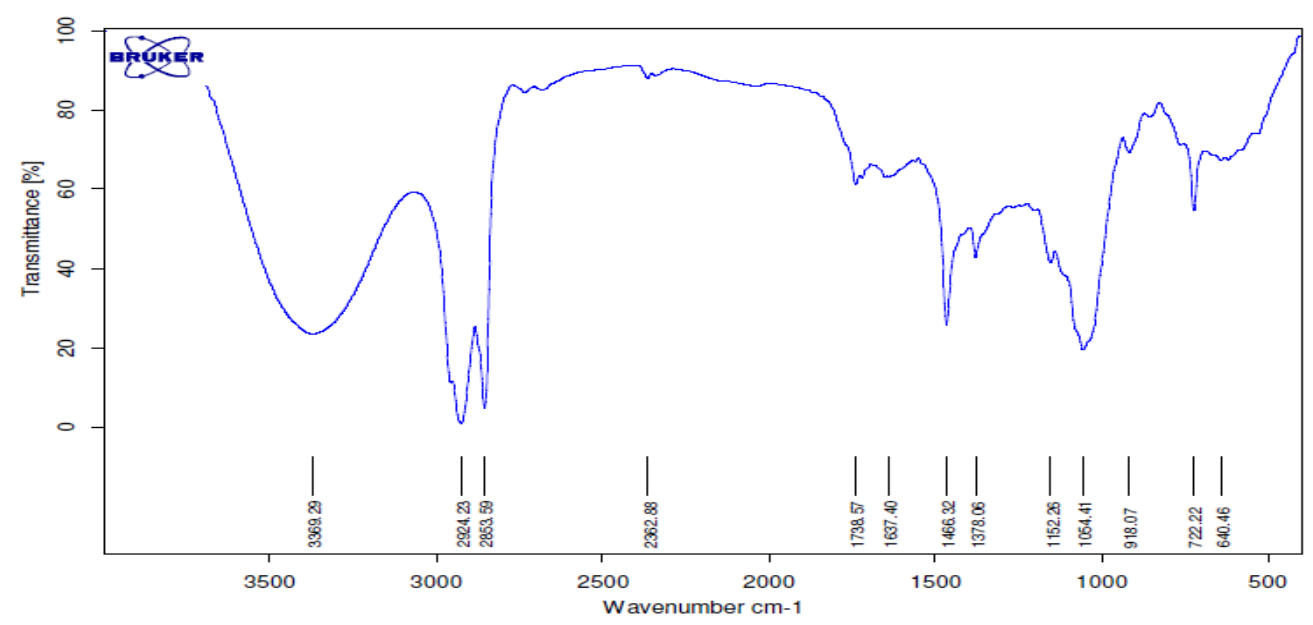

Gambar 4. Hasil analisa FTIR surfaktan APG $\left(\mathrm{C}_{12}\right)$

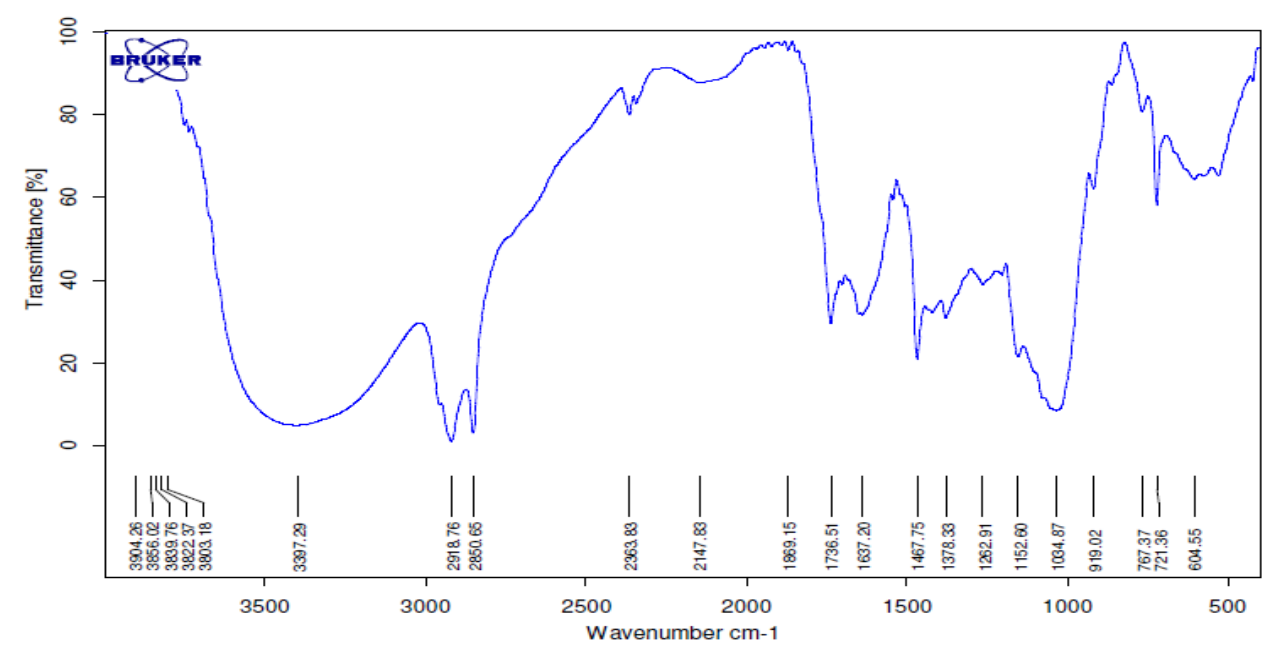

Gambar 5. Hasil analisa FTIR surfaktan APG $\left(\mathrm{C}_{16}\right)$ 


\section{Kinerja Surfaktan APG Tegangan Permukaan}

Tegangan permukaan merupakan suatu gaya yang timbul sepanjang garis permukaan suatu cairan. Gaya ini timbul karena adanya kontak antara dua cairan yang berbeda fase (Myers, 2006). Nilai tegangan permukaan surfaktan APG yang dihasilkan diukur dengan menggunakan spinning drop interfacial tensiometer TX500C. Rata-rata nilai tegangan permukaan APG hasil sintesis disajikan pada Gambar 6.

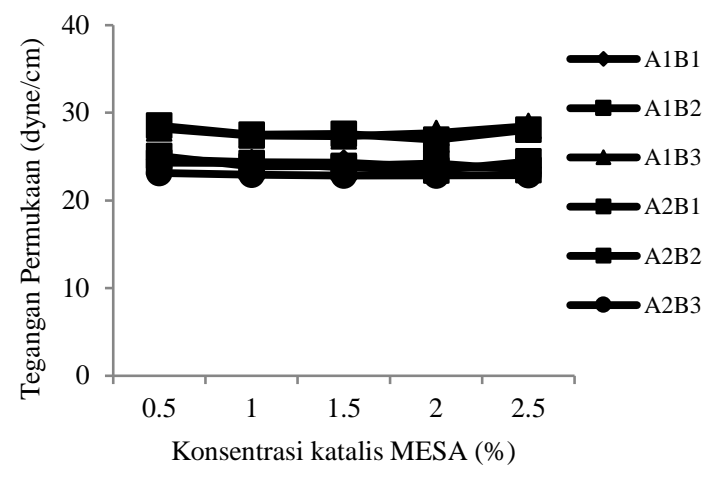

Keterangan :

A (jenis alkohol lemak); $\mathrm{A} 1=$ dodekanol $\left(\mathrm{C}_{12}\right) ; \mathrm{A} 2=$ heksadekanol $\left(\mathrm{C}_{16}\right)$

$\mathrm{B}$ (konsentrasi katalis MESA); $\mathrm{B} 1=1,5 \%$; $\mathrm{B} 2=2 \%$; $\mathrm{B} 3=$ $2,5 \%$

Gambar 6. Rata-rata nilai tegangan permukaan APG hasil sintesis

Tegangan permukaan air sebelum ditambahkan surfaktan APG adalah sebesar 72,40 dyne/cm. Hasil dari uji kemampuan menurunkan tegangan permukaan air dari APG yang dihasilkan menunjukkan kinerja yang baik. Dari perhitungan dengan konsentrasi APG $1 \%$, nilai tegangan permukaan bervariasi antara 22,73-28,81 dyne/cm dengan persentase kemampuan menurunkan tegangan permukaan air antara 60,37-68,24\%.

Hasil analisis ragam $(\alpha=0,05)$ menunjukkan bahwa jenis alkohol lemak, konsentrasi katalis dan interaksi antara keduanya berpengaruh nyata terhadap rata-rata kemampuan surfaktan APG dalam menurunkan tegangan permukaan air. Uji lanjut Duncan kombinasi perlakuan alkohol lemak $\mathrm{C}_{12}$ konsentrasi katalis $2 \%$ (A1B2) tidak berbeda nyata dengan perlakuan alkohol lemak $\mathrm{C}_{12}$ konsentrasi katalis 2,5\% (A1B3) dan keduanya berbeda nyata dengan kombinasi perlakuan alkohol lemak $\mathrm{C}_{12}$ konsentrasi katalis $1,5 \%$ (A1B1), alkohol lemak $\mathrm{C}_{16}$ konsentrasi katalis $1,5 \%$ (A2B1), alkohol lemak $\mathrm{C}_{16}$ konsentrasi katalis $2 \%$ (A2B2) dan alkohol lemak $\mathrm{C}_{16}$ konsentrasi katalis 2,5\% A2B3.

\section{Tegangan Antarmuka}

Perhitungan kemampuan menurunkan tegangan antar muka dilakukan pada larutan air dan xylene. Tegangan antar muka air dan xylene yaitu 42 dyne/cm. Konsentrasi penambahan APG hasil sintesis pada campuran air dan xylene yaitu $1 \%$. APG hasil sintesis dengan konsentrasi $1 \%$ memiliki nilai penurunan tegangan antar muka antara 0,74 1,72 dyne/cm atau memiliki nilai kemampuan penurunan tegangan antar muka 95,9-98,3\%. Ratarata nilai tegangan antarmuka APG hasil sintesis disajikan pada Gambar 7.



Gambar 7. Rata-rata nilai tegangan antarmuka APG hasil sintesis

Berdasarkan hasil analisis ragam $(\alpha=0,05)$ menunjukkan bahwa jenis alkohol lemak yang digunakan berpengaruh nyata terhadap kemampuan menurunkan tegangan antarmuka surfaktan APG yang dihasilkan. Sedangkan konsentrasi katalis MESA dan interaksi antara kedua faktor tidak berpengaruh nyata terhadap nilai tegangan antarmuka. Semakin panjang rantai atom karbon maka semakin besar kemampuan menurunkan tegangan antarmukanya Kemampuan menurunkan tegangan antarmuka tertinggi dihasilkan oleh surfaktan APG dengan kombinasi perlakuan alkohol lemak $\mathrm{C}_{16}$ dan katalis MESA 2,5\% (A2B3) sebesar $98,3 \%$. Sifat kepolaran dari surfaktan APG mempengaruhi kinerja dari surfaktan APG tersebut. Semakin tinggi gugus hidrofobik yang dimiliki oleh surfaktan, maka akan semakin tinggi pula kemampuan untuk menurunkan tegangan antarmuka. Pada surfaktan APG $\mathrm{C}_{16}$ terdapat kenaikan nilai tegangan antarmuka seiring dengan bertambahnya jumlah katalis MESA. semakin tinggi konsentrasi katalis MESA (methyl ester sulfonic acid) maka kemampuan APG dalam menurunkan tegangan antarmuka air-xylene menjadi lebih kuat. Hal ini diperkirakan karena katalis yang digunakan merupakan surfaktan. Pada APG $\mathrm{C}_{12}$ penambahan konsentrasi katalis MESA mengakibatkan penurunan nilai tegangan antarmuka karena penambahan katalis telah mencapai kejenuhan.

\section{Stabilitas Emulsi}

Emulsi merupakan penyatuan dari dua atau lebih jenis larutan yang tidak saling larut, salah satu cairan terdispersi ke dalam cairan yang lain. Namun 
karena perbedaan berat molekul ataupun karena pengaruh gaya kohesi maka larutan tersebut secara perlahan akan terpisah lagi. Penghitungan kestabilan emulsi dilakukan dengan menambahkan APG 1\%, $3 \%$ dan 5\% pada laruran air dan xylene kemudian dikocok dengan menggunakan vortex dan didiamkan selama 300 menit, tinggi emulsi yang terbentuk kemudian diukur untuk melihat kestabilan emulsinya. Rata-rata stabilitas emulsi surfaktan APG hasil sintesis disajikan pada Gambar 8 .

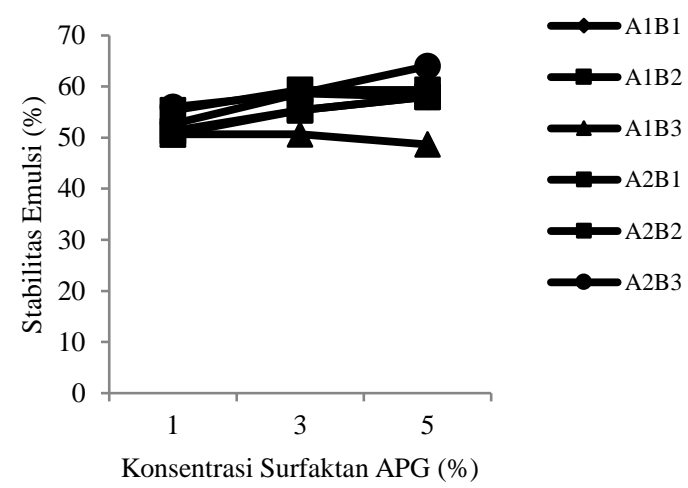

Keterangan:

A (jenis alkohol lemak); $\mathrm{A} 1=$ dodekanol $\left(\mathrm{C}_{12}\right) ; \mathrm{A} 2=$ heksadekanol $\left(\mathrm{C}_{16}\right)$

$\mathrm{B}$ (konsentrasi katalis MESA); B1 = 1,5\%; B2 $=2 \%$; B3 $=2,5 \%$

Gambar 8. Rata-rata stabilitas emulsi surfaktan APG hasil sintesis

Hasil sintesis surfaktan APG diperoleh ratarata stabilitas emulsi antara air dan xylene dengan penambahan konsentrasi surfaktan APG sebesar 1\% pada pengamatan 300 menit berkisar antara 50-56\%. Sedangkan pada konsentrasi APG 3\% berkisar antara 51- 60\% dan pada konsentrasi APG 5\% berkisar antara $48-65 \%$.

Berdasarkan hasil analisis ragam, pada konsentrasi surfaktan APG 1\% jenis alkohol lemak dan interaksi kedua faktor berpengaruh nyata terhadap stabilitas emulsi sedangkan konsentrasi katalis MESA tidak berpengaruh nyata terhadap nilai stabilitas emulsi. Sedangkan pada konsentrasi surfaktan APG 3\% dan 5\% jenis alkohol lemak, konsentrasi katalis dan interaksi kedua faktor berpengaruh terhadap stabilitas emulsi $(\alpha=0,05)$. Surfaktan dari jenis alkohol lemak $\mathrm{C}_{16}$ memiliki kemampuan meningkatkan stabilitas emulsi yang lebih tinggi dibandingkan dengan alkohol lemak $\mathrm{C}_{12}$. Semakin panjang gugus hidrofobik yang dimiliki oleh surfaktan APG, maka kelarutan surfaktan dalam larutan nonpolar akan lebih tinggi.

\section{Pembusaan}

Busa cair adalah sistem koloid dengan fase terdispersi gas dan medium pendispersi zat cair. Kestabilan busa diperoleh dari adanya zat pembusa (surfaktan). Zat pembusa ini teradsorpsi ke daerah antar fase dan mengikat gelembung-gelembung gas sehingga diperoleh suatu kestabilan. Penghitungan tinggi busa dilakukan dengan konsentrasi APG $0,5 \%$. Rata-rata tinggi busa surfaktan APG hasil analisis disajikan pada Gambar 9 .

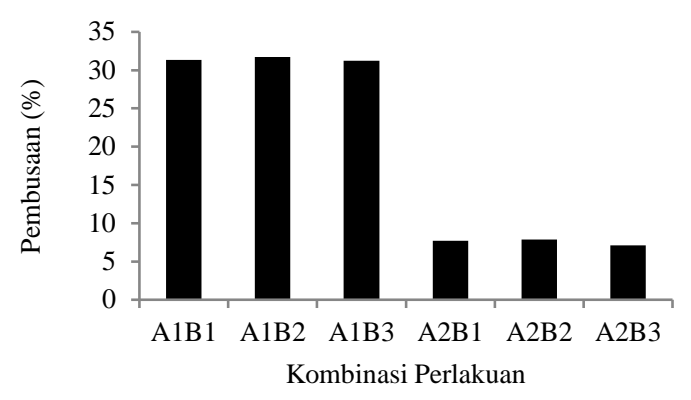

Keterangan:

A (jenis alkohol lemak); $\mathrm{A} 1=$ dodekanol $\left(\mathrm{C}_{12}\right) ; \mathrm{A} 2=$ heksadekanol $\left(\mathrm{C}_{16}\right)$

$\mathrm{B}$ (konsentrasi katalis MESA); $\mathrm{B} 1=1,5 \%$; $\mathrm{B} 2=2 \%$; $\mathrm{B} 3=$ $2,5 \%$

Gambar 9. Rata-rata tinggi busa surfaktan APG hasil analisis

Keberadaan busa pada APG dipengaruhi oleh jenis alkohol lemak yang digunakan. Surfaktan APG yang disintesis dari bahan baku alkohol lemak $\mathrm{C}_{12}$ menghasilkan busa yang lebih banyak dibandingkan dengan surfaktan APG dari bahan baku alkohol lemak $\mathrm{C}_{16}$. Analisis ragam menunjukkan jenis alkohol lemak berpengaruh terhadap kemampuan pembusaan sedangkan konsentrasi katalis dan interaksi kedua faktor tidak berpengaruh nyata $(\alpha=0,05)$. Uji lanjut Duncan menunjukkan tinggi busa alkohol lemak $\mathrm{C}_{12}$ berbeda nyata dengan tinggi busa alkohol lemak $\mathrm{C}_{16}$. Kemampuan surfaktan dipengaruhi oleh panjang rantai karbon penyusunnya, $\mathrm{C}_{16}-\mathrm{C}_{18}$ berperan terhadap kekerasan dan sifat detergensi, sedangkan $\mathrm{C}_{12}-\mathrm{C}_{14}$ berperan terhadap efek pembusaan yang baik (Hambali et al., 2012).

\section{KESIMPULAN DAN SARAN}

\section{Kesimpulan}

Jenis alkohol lemak (fatty alcohol) mempengaruhi karakteristik surfaktan APG yang dihasilkan yaitu tegangan permukaan, tegangan antarmuka, stabilitas emulsi dan pembusaan. Surfaktan APG $\mathrm{C}_{16}$ memiliki kemampuan untuk menurunkan nilai tegangan permukaan dan tegangan antarmuka yang lebih tinggi dan nilai stabilitas emulsi yang lebih tinggi dibandingkan dengan Surfaktan APG $\mathrm{C}_{12}$. Surfaktan APG $\mathrm{C}_{12}$ memiliki kemampuan pembusaan yang lebih tinggi dibandingkan dengan surfaktan APG $\mathrm{C}_{16}$.

Surfaktan APG $\mathrm{C}_{16}$ memiliki karakteristik yang lebih baik dibandingkan dengan surfaktan APG $\mathrm{C}_{12}$. Surfaktan APG $\mathrm{C}_{16}$ dengan konsentrasi katalis MESA 2,5\% memiliki karakteristik nilai rata-rata 
kemampuan menurunkan tegangan permukaan sebesar $68,12 \%$, kemampuan menurunkan tegangan antarmuka 98,14\%, stabilitas emulsi 64\%, pH 7,69 dan pembusaan $7,12 \%$.

\section{Saran}

Perlu dilakukan penelitian lebih lanjut untuk rasio mol antara glukosa dan alkohol lemak karena alkohol lemak masih bersisa serta penggunaan reaktan glukosa cair dengan berbagai konsentrasi dan berbagai sumber karbohidrat dan aplikasi surfaktan APG dalam produk.

\section{DAFTAR PUSTAKA}

Bastian F, Suryani A, dan Sunarti TC. 2012. Peningkatan kecerahan pada proses sintesis surfaktan non ionik alkil poliglikosida (APG) berbasis tapioka dan dodekanol. $J$ Reaktor. 14(3):43-150.

Eskuchen R dan Michael N. 1997. Technology and Production of Alkyl Poliglycosides. Di dalam : Hill K, von Rybinski W, Stoll, G., Editor. 1997. Alkyl Polyglicoside: Technology, Properties and Applications. New York : VCH Publishers. hlm : $10-11$.

Hambali E, Pudji P, Yuni A, Ani S, Mira R, Padil, Cahyo P. 2012. Pemilihan konsentrasi katalis PTSA untuk sintesis surfaktan alkil poliglikosida dari Palm Fatty Alcohol $\left(\mathrm{C}_{16}\right)$ dan glukosa cair $85 \%$ dari singkong untuk aplikasi EOR. Prosiding Insinas. 2012.

Hill K. 2009. Alkyl polyglycosides-where green meets performance. Soft J. 2: 6-14.
Luders H. 2000. Structure and Nomenclature of Surface-Active Alkyl Glucosides. Di dalam : Balzer D and Luders H, editor. Noninonic Surfactants Alkyl Polyglucosides. Ed ke-10. USA: Marcel Dekker. Hlm 1-75.

McCurry Pattrick Jr, Klein, Robert L, Gibson, Michael W, Beaulieu, James D, Varvil Janet R. 1994. Penemu: United States Patent, 8 November 1994. Continuous bleaching of alkylpolyglycosides. US5362861.

Myers D. 2006. Surfactant Science and Technology. $3^{\text {rd }}$ ed. New Jersey (US): John Wiley \& Sons, Inc.

Mehling A, Kleber M, dan Hensen H. 2007. Comparative studies on the ocular and dermal irritation potential of surfactants. $J$ Food Chem Toxicol. 14 :747-758.

O'Lenick Jr. 2007. Penemu ; United States Patent, 13 Maret 2007. Non-ionic Surfactant Based Upon Alkyl Poliglucosides. US7189683.

Sukkary MMA, Syed NA, Aiad I, El-Azab WIM. 2008. Synthesis and characterization of some alkyl polyglycosides surfactans. $J$ Surfactant and Detergents 11(2):129-137.

Suryani A, Dadang, Setyadjit, Tjokrowardoyo AS, Noerdin M. 2008. Sintesis alkilpoliglikosida (APG) berbasis alkohol lemak dan pati sagu untuk formulasi herbisida. J Pascapanen. 5 (1):10-20.

Ware AM, Waghmare JT, dan Momin SA. 2007. Alkylpolyglycoside: Carbohydrate based surfactant. J Dispersion Sci Technol. 28: 437-444. 